\title{
Analysis of mediation effect of country-of-origin image on brand equity
}

\author{
Vishal Jain* \\ Rustaq College of Education, \\ Ministry of Higher Education, Sultanate of Oman \\ Email: vishal.dr.jain@gmail.com \\ *Corresponding author
}

\author{
Shalini Bariar \\ Vivekanand Education Society Institute of \\ Management Studies and Research, \\ Chembur, Mumbai, India \\ Email: shalinibariar@gmail.com
}

\begin{abstract}
Marketers are required to study consumer psyche for the development of sustainable competitive advantage over other brands. One of the most significant challenges for marketing professionals is the ability to create, maintain and enhance brand equity, as it is the most critical indicator of the product performance. The purpose of this research is to investigate a theoretical framework in which brand's country-of-origin image is suggested to influence the level of brand equity of hair care products. It also studies the mediation effects of various dimensions of brand equity, which are brand loyalty, brand awareness, brand association and perceived quality. The study shows that in the absence of mediators the country-of-origin image has a positive and significant effect on brand equity. However, in the presence of mediators the relationship becomes insignificant, which confirms the mediation effect. The present study will be useful to create the right message for the target customers.
\end{abstract}

Keywords: country-of-origin image; brand equity; brand loyalty; brand awareness; brand association; perceived quality.

Reference to this paper should be made as follows: Jain, V. and Bariar, S. (2019) 'Analysis of mediation effect of country-of-origin image on brand equity', Int. J. Business and Data Analytics, Vol. 1, No. 1, pp.89-109.

Biographical notes: Vishal Jain is an Assistant Professor in the Rustaq College of Education, Ministry of Higher Education, Sultanate of Oman. He holds a $\mathrm{PhD}, \mathrm{MBA}, \mathrm{PGDCA}$ and BSc and has 19 years of rich experience in industry and academia. His academic contributions include a number of articles, chapters and conference papers. His main research areas include marketing, retailing, and social sciences.

Shalini Bariar is an Associate Professor in the Vivekanand Education Society Institute of Management Studies and Research, Chembur, Mumbai, India. She holds a $\mathrm{PhD}$ in Marketing since 2012, with overall 16 years of working experience in academics and advertising industry. She is involved in research 
projects and holds consultancy projects in branding and marketing communications. Her research interests are related to IMC, branding, and consumer behaviour.

This paper is a revised and expanded version of a paper entitled 'Relationship between country-of-origin image and brand equity of hair care products mediated by dimensions of brand equity' presented at MTMI Conference, Dubai, UAE, 16-17 December 2017.

\section{Introduction}

The marketing activities have been booming over the past decade due to the globalisation and market proliferation. Organisations should wisely evaluate the performance of their marketing strategies with a special reference to branding strategies (Cassia et al., 2017). Various brands have crossed boundaries, established themselves in the global markets and are being preferred by the worldwide consumers over the period. At the same time, the local, regional and national brands find the market highly competitive and are engrossed in marketing activities to sustain and grow in the market. In the current competitive environment, it is essential for the brand marketers to endeavour hard to stay in the relevant market (Hosseini and Saravi Moghadam, 2017). Building a brand stronger and stronger over time is a marketing challenge for the organisations (Bariar et al., 2016). Strong brands can sustain in the mind of the customers for a more extended period. Strong brands provide a competitive advantage to the firm by creating an identity in the marketplace (Aaker, 2012). It helps an organisation in the development of a sustainable brand equity and enjoys a brand advantage in the given market. Brand equity is one of the most important marketing concepts that study the strength of the brand. If properly assessed, brand equity can have a long-lasting impact on marketing decisions.

The consumer's changing lifestyle also adds on to the increased marketing opportunities for the brands. Consumer's growing emphasis on beauty and appearance boosted the growth of the entire personal care industry. In the development of the market and consumer demand, the hair care products also registered a substantial growth in the Indian market during the current decade. Hair care industry displayed current value growth of $8 \%$ in the previous year, with sales approximately INR 192.8 billion (Research and Markets, 2017). However, Indian consumers are gradually becoming conscious of the harmful effects of chemicals and are ready to spend more time and money to select their preferred brand. Currently, purchases are based on customer's perception of the haircare products that state the characteristics of the ingredients, such as, Chemicals, natural, herbal or Ayurveda. The hair care industry operating in India requires a comprehensive study to analyse the market at a national level to understand the customer purchase for a specific brand. There is a need to study the consumer purchase decision to select a particular brand among plenty of international brands available in the haircare market. The study of brand equity is required to be done to analyse the brand strength. Present study is sought to explore various dimensions that affect the consumer's purchase decisions based on brand equity of the haircare products in the Indian market. 
In addition, with the advent of various international brands in the market, many times consumer gives importance to the country-of-origin image of the product as one of the attributes along with other brand equity dimensions for generating product preference. It is believed that brand's country-of-origin image is one of the sources of brand equity as it forms one of the reasons to influence the purchase decision. Present research primarily examines the relationships of the country-of-origin image with brand equity and its dimensions. It also attempts to understand the mediation effect of the country-of-origin image on brand equity. Findings of the study will certainly help the international brands to serve Indian hair care consumers from the point of the country-of-origin image and its effects on purchase decisions when mediated by dimensions of brand equity.

\section{Literature review}

In the era of a highly competitive environment, building strong brands turn out to be a marketing priority (Bassan and Kathuria, 2016). Branding has a tremendous significance for the marketers and consumers. Researchers consider the unbranded product as a commodity and the brand as a lens, which helps the consumers to form an opinion regarding the product and the organisation (Blythe, 2007). Consumer satisfaction depends on functional and emotional features offered by the brands (Hankinson and Cowking, 1996). Customers view the various attributes and benefits associated with a product through the branding strength, and thus brand becomes a critical variable in consumer purchase decisions. It builds consumer loyalty towards a particular brand that provides superior margins, better intermediary cooperation, brand extension prospects and is less vulnerable to the competitive situations (Ballester and Alemán, 2005). Branding has become the major concern and prime challenge in the business and marketing strategies in the highly competitive market (Opoku et al., 2006).

The country-of-origin image also has a significant impact in developing consumers' trust about attributes and influences the evaluation process of the brands (Lin and Chen, 2006). Srikatanyoo and Gnoth (2002) mentioned that consumers develop prevailing opinions regarding products originating from a particular country and relate it to the product attributes. The country-of-origin image represents the home country for a company or the country that consumer infers from the brand name (Mahyari et al., 2018). Companies should capitalise on this while deciding branding strategies as it leads to a significant positive impact on brand equity (Lee et al., 2014).

Therefore, it is essential to create a robust brand for the success of the business (Mutsikiwa et al., 2013). To measure the real worth of a brand, marketers, and researchers investigate the product's 'brand equity' (Aaker, 1991; Baldinger, 1990; Keller et al., 2011). Table 1 given includes some of the studies in the field of the country-of-origin image, brand equity, and its dimensions.

Table 1 literature suggests that a plethora of studies are available to measure the brand equity in terms of its dimensions. It is also evident that scholars have used different sets of brand equity dimensions for different product categories. However, the most accepted dimensions are brand awareness, perceived quality, brand association, and brand loyalty (Aaker, 1991). Findings of some the studies combine brand awareness and brand association as one dimension. Few of the studies highlight the direct and indirect effects of the country-of-origin image on brand equity. 
Table 1 Previous studies

\begin{tabular}{|c|c|c|c|c|}
\hline Study & Causal variable & Dimensions & Relationship & Outcome \\
\hline Akhtar et al. (2016) & & Brand awareness & Positive significant & Purchase \\
\hline \multirow[t]{3}{*}{ Skincare products } & & Perceived quality & Negative significant & \\
\hline & & Brand association & Negative significant & \\
\hline & & Brand loyalty & Positive significant & \\
\hline $\begin{array}{l}\text { Akkucuk and } \\
\text { Esmaeili (2016) }\end{array}$ & & Brand awareness & Positive significant & $\begin{array}{l}\text { Brand } \\
\text { equity }\end{array}$ \\
\hline \multirow[t]{3}{*}{ Smartphone } & & Perceived quality & Insignificant & \\
\hline & & Brand association & Insignificant & \\
\hline & & Brand loyalty & Positive significant & \\
\hline Al-Aali et al. (2015) & $\begin{array}{l}\text { Country of } \\
\text { assembly }\end{array}$ & Price & Positive significant & $\begin{array}{l}\text { Purchase } \\
\text { intention }\end{array}$ \\
\hline \multirow[t]{2}{*}{ Theoretical model } & Country of design & Quality & Positive significant & \\
\hline & Country of parts & Brand loyalty & Positive significant & \\
\hline Atilgan et al. (2005) & & Brand awareness & Insignificant & Brand \\
\hline \multirow[t]{3}{*}{ Beverage industry } & & Perceived quality & Insignificant & equity \\
\hline & & Brand association & Insignificant & \\
\hline & & Brand loyalty & Positive significant & \\
\hline $\begin{array}{l}\text { Ayyildiz and } \\
\text { Cengiz (2007) }\end{array}$ & Country image & Perceived quality & Positive significant & $\begin{array}{l}\text { Word of } \\
\text { mouth }\end{array}$ \\
\hline \multirow[t]{4}{*}{ Hot springs } & & Customer expectation & Positive significant & \\
\hline & & Perceived value & Positive significant & \\
\hline & & Customer satisfaction & Positive significant & \\
\hline & & Customer loyalty & Positive significant & \\
\hline Azadi et al. (2015) & $\begin{array}{l}\text { Country-of-origin } \\
\text { image }\end{array}$ & $\begin{array}{c}\text { Brand } \\
\text { awareness/association }\end{array}$ & Positive significant & $\begin{array}{l}\text { Brand } \\
\text { equity }\end{array}$ \\
\hline \multirow{2}{*}{$\begin{array}{l}\text { Sports apparel } \\
\text { industry }\end{array}$} & & Perceived quality & Positive significant & \\
\hline & & Brand loyalty & Positive significant & \\
\hline $\begin{array}{l}\text { Bahrinizadeh et al. } \\
\text { (2014) }\end{array}$ & $\begin{array}{l}\text { Country-of-origin } \\
\text { image }\end{array}$ & Brand awareness & Positive significant & $\begin{array}{l}\text { Brand } \\
\text { equity }\end{array}$ \\
\hline \multirow{3}{*}{$\begin{array}{l}\text { Pharmaceutical } \\
\text { industry }\end{array}$} & & Perceived quality & Insignificant & \\
\hline & & Brand image & Positive significant & \\
\hline & & Brand loyalty & Positive significant & \\
\hline Buil et al. (2013) & & Brand awareness & NA & Brand \\
\hline \multirow[t]{3}{*}{ Consumer goods } & & Perceived quality & Positive significant & \\
\hline & & Brand association & Positive significant & \\
\hline & & Brand loyalty & Positive significant & \\
\hline $\begin{array}{l}\text { Ballester and } \\
\text { Alemán (2005) }\end{array}$ & $\begin{array}{l}\text { Overall } \\
\text { satisfaction }\end{array}$ & Brand reliability & Positive significant & $\begin{array}{l}\text { Brand } \\
\text { equity }\end{array}$ \\
\hline Shampoo and beer & & Brand intentions & Positive significant & \\
\hline
\end{tabular}


Table 1 Previous studies (continued)

\begin{tabular}{|c|c|c|c|c|}
\hline Study & Causal variable & Dimensions & Relationship & Outcome \\
\hline Shampoo and beer & $\begin{array}{c}\text { Overall } \\
\text { satisfaction }\end{array}$ & Brand loyalty & Positive significant & $\begin{array}{l}\text { Brand } \\
\text { equity }\end{array}$ \\
\hline $\begin{array}{l}\text { Hamzaoui and } \\
\text { Merunka (2006) }\end{array}$ & $\begin{array}{c}\text { Country of design } \\
\text { image }\end{array}$ & Perceived quality & Positive significant & \\
\hline Car and TV & $\begin{array}{l}\text { Country of } \\
\text { manufacture } \\
\text { image }\end{array}$ & & Positive significant & \\
\hline $\begin{array}{l}\text { Hilman and } \\
\text { Hanaysha (2015) }\end{array}$ & $\begin{array}{l}\text { Country-of-origin } \\
\text { image }\end{array}$ & Brand trust & Positive significant & \\
\hline \multirow{3}{*}{$\begin{array}{l}\text { Automotive } \\
\text { industry }\end{array}$} & & Brand commitment & Positive significant & \\
\hline & & Brand satisfaction & Positive significant & \\
\hline & & Overall quality & Positive significant & \\
\hline Lassar et al. (1995) & Performance & NA & Brand equity & \\
\hline \multirow[t]{4}{*}{ TV and watches } & & Social image & NA & \\
\hline & & Value & NA & \\
\hline & & Trustworthiness & NA & \\
\hline & & Attachment & NA & \\
\hline Mostafa (2015) & Country-of-origin & Brand awareness & Positive significant & \multirow{4}{*}{$\begin{array}{l}\text { Brand } \\
\text { equity }\end{array}$} \\
\hline \multirow[t]{3}{*}{ Mobile phones } & Country-of- & Perceived quality & Positive significant & \\
\hline & & Brand image & Positive significant & \\
\hline & & Brand loyalty & Positive significant & \\
\hline $\begin{array}{l}\text { Sanyal and Datta } \\
\text { (2011) }\end{array}$ & $\begin{array}{l}\text { Country-of-origin } \\
\text { image }\end{array}$ & Brand strength & Positive significant & \multirow[t]{2}{*}{$\begin{array}{l}\text { Brand } \\
\text { equity }\end{array}$} \\
\hline Generic drugs & & Brand awareness & Positive significant & \\
\hline Ngoc (2014) & Country-of-origin & Perceived quality & Positive significant & \multirow{3}{*}{$\begin{array}{l}\text { Brand } \\
\text { equity }\end{array}$} \\
\hline \multirow[t]{2}{*}{ Cosmetic } & & Brand loyalty & Positive significant & \\
\hline & & $\begin{array}{c}\text { Brand } \\
\text { awareness/association }\end{array}$ & Insignificant & \\
\hline $\begin{array}{l}\text { Panda and Misra } \\
\text { (2014) }\end{array}$ & Country-of-origin & Brand awareness & Positive significant & $\begin{array}{l}\text { Brand } \\
\text { equity }\end{array}$ \\
\hline \multirow[t]{2}{*}{ Durables } & & Brand loyalty & Positive significant & \\
\hline & & Brand distinctiveness & Positive significant & \\
\hline $\begin{array}{l}\text { Tong and Hawley } \\
\text { (2009) }\end{array}$ & & Brand awareness & Insignificant & \multirow[t]{4}{*}{$\begin{array}{l}\text { Brand } \\
\text { equity }\end{array}$} \\
\hline Sportswear & & Perceived quality & Insignificant & \\
\hline & & Brand association & Positive significant & \\
\hline & & Brand loyalty & Positive significant & \\
\hline \multirow{3}{*}{$\begin{array}{l}\text { Yasin et al. (2007) } \\
\text { Electrical } \\
\text { appliances }\end{array}$} & Country-of-origin & Brand distinctiveness & Positive significant & \multirow{3}{*}{$\begin{array}{l}\text { Brand } \\
\text { equity }\end{array}$} \\
\hline & & Brand loyalty & Positive significant & \\
\hline & & $\begin{array}{c}\text { Brand } \\
\text { awareness/association }\end{array}$ & Positive significant & \\
\hline
\end{tabular}




\subsection{Brand equity (BE)}

Many researchers have mentioned brand equity as a treasured intangible asset that offers numerous benefits to the marketing organisations (Aaker, 1991, 1996, 2012; Keller, 1993; Keller et al., 2011). Yoo and Donthu (2001) defined the brand equity as the difference in the consumer preference amidst the branded and unbranded products. Atilgan et al. (2005) refined the definition by elucidating the word 'difference' as 'the utility difference' regarding a positive marketing effect, generated by a branded product as compared to that of the generic version of the similar product. Companies with positive and ethical brand equity can maximise the product life by applying brand extension strategies and minimise the chances of product failure (Datta and Mukherjee, 2017). Bello and Holbrook (1995) stated that the brand equity appears when consumers are willingly paying more for the similar quality of the appeal of the brand name attached to the product.

\subsection{Brand equity dimensions}

Increased marketing efforts add more dimensions to the brand equity. Shocker and Weitz (1988) recognised brand loyalty and brand image as two critical components for developing brand equity. On the other hand, Fathi et al. (2017) identified eight dimensions of brand equity. Aaker (1991) proposed a well-accepted model, which shows that brand equity comprises of four essential dimensions; brand loyalty, brand awareness, brand association, and perceived quality. Further, other researchers (Keller, 1993; Yoo and Donthu, 2001) studied the consumer based brand equity measures under the same dimensions and found that these dimensions collectively increase the brand equity.

\subsubsection{Brand loyalty $(B L)$}

Studies have shown that loyal consumers display more favourable responses to a brand than non-loyal or switching consumers do (Grover and Srinivasan, 1992; Rondán Cataluña et al., 2006). Haghighi et al. (2013) presented that when a brand attains customer loyalty, it offers several advantages, such as; cost saving, greater commercial power, protecting customers from switching brands, and higher profitability. Brand loyalty refers to the willingness of the customer to purchase the same brand repeatedly without any intention to switch to competitive brands (Hameed, 2013). Hence, brand loyalty becomes an essential determinant of developing brand equity. Aaker (1991) described brand loyalty as the level of attachment of the customer with the brand. Brand equity heavily depends upon the repurchase of a brand (Aaker, 1996) and therefore, higher brand loyalty leads to higher brand equity (Atilgan et al., 2005; Mostafa, 2015). Oliver (1997) explained that the brand loyalty is a strong commitment towards the repeat purchase of a favoured product for an extended period. Besides, the environmental and marketing influences for switching brand are not affecting it. Azadi et al. (2015) and Kumar et al. (2013) confirmed that brand loyalty is the core influencing factor in the forming brand equity of the product. Some of the previous studies (Bahrinizadeh et al., 2014; Hilman and Hanaysha, 2015; Panda and Misra, 2014; Sanyal and Datta, 2011) also suggested that the effect of the country-of-origin image on brand loyalty is significant. Based on the literature, the following hypotheses are formulated: 
$\mathrm{H}_{\mathrm{a} 1} \quad$ Country-of-origin image has a significant positive effect on brand loyalty.

$\mathrm{H}_{\mathrm{b} 1} \quad$ Brand loyalty has a significant positive effect on brand equity.

\subsubsection{Brand awareness and brand association (BA)}

Brand awareness plays a significant role in the consumer decision making (Keller, 1993). Consumers prefer to purchase a product that they know already. It leads to creating a positive brand equity and therefore, brand awareness is one of the essential determinants of building brand equity (Aaker, 1991). Buil et al. (2013) inferred that brand awareness is needed for the establishment of a brand that consumer must know that it exists. Chattopadhyay et al. (2008) connected brand awareness with consumer's memory because it is formed of brand recognition and brand recall. Aaker (1996) further extended brand awareness dimensions to six categories namely; recognition, recall, top of the mind recall, supremacy, knowledge, and opinion.

The consumer purchase behaviour significantly depends on the image associated with the brand (Belén del Río et al., 2001). The high level of brand association adds high value towards building positive brand equity. Therefore, Aaker (1991) considered brand association as an essential dimension of brand equity. Yoo et al. (2000) linked brand association with the memory; how well consumer relates the brand. Several studies (Buil et al., 2013; Kumar et al., 2013; Pappu et al., 2006; Tong and Hawley, 2009; Ye and Raaij, 2004) successfully tested the brand associations as a dimension of brand equity and found it suitable for various products in different markets.

Amiri and Maroofi (2016) witnessed that previous studies consider brand awareness and brand associations as a joint dimension of brand equity. Ngoc (2014) observed that brand awareness/association, which is an essential determinant in the purchase decisions, has a significant relationship with the country-of-origin image. The brands with the positive country-of-origin image are well recognised, which leads to purchasing intentions. Panda and Misra (2014) and Yasin et al. (2007) found linkage between country-of-origin image and brand equity through brand awareness/association. Based on the literature, the following hypotheses are formulated:

$\mathrm{H}_{\mathrm{a} 2} \quad$ Country-of-origin image has a significant positive effect on brand awareness/association.

$\mathrm{H}_{\mathrm{b} 2}$ Brand awareness/association has a significant positive effect on brand equity.

\subsubsection{Perceived quality $(P Q)$}

Zeithaml (1988) argued perceived quality as the assumption regarding the superiority of the quality of a product based on different factors. It becomes the primary reason for developing the brand preference and influencing purchase intentions. Hence, it is considered a significant determinant of the brand equity (Aaker, 1991; Keller et al., 2011). Higher perceived quality forms a basis for the price premium, provides price elasticity and increases brand usage (Aaker, 1996). Therefore, high-perceived quality influences the consumer's choice and leads to increased brand equity (Hanaysha et al., 2016). Steenkamp (1997) identified intrinsic and extrinsic attributes that influence quality perception. The country-of-origin image is considered as an extrinsic attribute of the product. Huber and McCann (1982) stated that in the case when the actual quality of the 
brand is not judged clearly, the country-of-origin image influences perceived the quality of the product. Based on the literature, the following hypotheses are formulated:

$\mathrm{H}_{\mathrm{a} 3}$ Country-of-origin image has a significant positive effect on perceived quality.

$\mathrm{H}_{\mathrm{b} 3}$ Perceived quality has a significant positive effect on brand equity.

\subsection{Country-of-origin image (CO)}

Country-of-origin image of a product is considered a crucial aspect that influences customer's perception of the brand (Kim, 1995). Nagashima (1970) described the concept of country-of-origin as the image that consumers associate with the brands. Shahrokh and Azodi (2013) examined that customers incline towards that products or services of particular brands that are made in countries associated with positive images. The country-of-origin image is developed because of the national characteristics and perception of the particular country (Bilkey and Nes, 1982). Some studies interpret the country image as consumers' perceptions regarding the quality of the product made in that country (Parameswaran and Yaprak, 1987; Shahin et al., 2012). While other studies consider country-of-origin as the beliefs about a country's industrialisation and national quality standard (Hilman and Hanaysha, 2015; Srikatanyoo and Gnoth, 2002). The country-of-origin image is related to the attributes, such as reputation of brand name, product design, appearance, variety, durability, technical advancement, trustworthiness, workmanship and status symbol (Hamzaoui and Merunka, 2006). It provides extrinsic cues regarding the quality to the consumers (Cordell, 1992; Saydan, 2013; Thorelli et al., 1989).

Lin and Kao (2004) developed a model that links country-of-origin image effects to brand equity. Azadi et al. (2015), Yasin et al. (2007) and Yoo and Donthu (2001) examined that brand's country-of-origin image for various products has a substantial influence on brand equity dimensions. Further, Ayyildiz and Cengiz (2007) and Shahin et al. (2012) shown that country-of-origin image affects the brand awareness/association, brand loyalty, and brand image of a product. Yasin et al. (2007) on consumer goods and Panda and Misra (2014) on durable products concluded that country-of-origin image leads to improved brand equity. In addition, its determinants have mediating effects on the linkage between country-of-origin image and brand equity. Based on the literature, the following hypotheses are formulated:

$\mathrm{H}_{c} \quad$ Country-of-origin image has a significant positive effect on brand equity in the absence of the mediators.

$\mathrm{H}_{\mathrm{c}^{\prime}} \quad$ Country-of-origin image has an insignificant effect on brand equity in the presence of the mediators.

\section{Problem statement, research gap, and research model}

The results of the previous researches done in other markets build a framework to develop a constructive approach to the hair care companies in their marketing strategies. Review of the literature clearly highlights the relationships among country-of-origin image, brand equity dimensions and brand equity. It is also evident from the literature that these relationships vary for different products and markets. In this field, there is lack 
of research that studies the hair care products, especially in the Indian market. This research analyses the relationships among country-of-origin image, brand equity dimensions and brand equity for hair care products in Indian market. The following are the main objectives of this research:

1 To determine the effect of the country-of-origin image on brand equity dimensions of hair care products.

2 To find out the link between brand equity and its dimensions of hair care products.

3 To establish the direct and indirect relations of the country-of-origin image on the formation of brand equity of hair care products.

With these three objectives, paper aims to study the relationship of the country-of-origin image in developing the brand equity of hair care products mediated by dimensions of brand equity. The present study is based on conceptual framework reflected in Figure 1, which explains the relationship among the country-of-origin image, brand equity dimensions and brand equity. Brand's country-of-origin image is suggested to influence the extent of brand equity, which is formed by its dimensions, namely; brand loyalty, brand awareness, brand associations, and perceived quality.

Figure 1 Conceptual framework (see online version for colours)

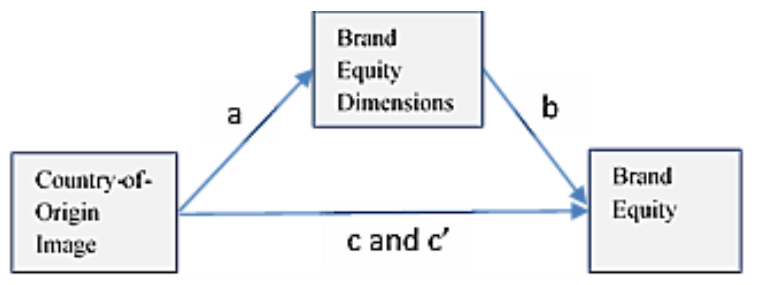

\section{Research methodology}

A survey was conducted in Mumbai (India) to understand consumers' perception towards the haircare brands. Mumbai, known as financial capital of India, is one of the suitable locations to conduct a research on branding. Present study is a causal research design that looks at the effect of the country-of-origin image on brand equity. It also investigates the mediation effect, where country-of-origin image is assumed as causal variable, brand equity as outcome and dimensions of brand equity as mediators. A questionnaire was designed that consists of various constructs of the conceptual model recognised in the literature review. After pretest, 30 items were identified to depict all constructs that were measured by a reflective five-point Likert scale from 1 (strongly disagree) to 5 (strongly agree). A convenience sampling method was undertaken where questionnaires were distributed among the colleagues, friends and relatives during August and September 2017. In the course of the initial screening of the collected data, it was observed that only 278 respondents completed the questionnaires. Present study incorporates three major tools to analyse the collected data. First, exploratory factor analysis (EFA) to identify all the factors and their items. Second, confirmatory factor analysis (CFA) to test whether 
the data fit a hypothesised measurement model. Finally, multivariate analysis (Hayes, 2017) to examine the mediation effect.

\section{Analysis and results}

KMO and Bartlett's test (Table 2) of sampling adequacy was performed to check the suitability of factor analysis. KMO value for this study is 0.938 and has been found to be adequate. Bartlett's test of sphericity, which measures the multivariate normality of set of distributions, is significant (chi-square value $=8,390.204$, $\mathrm{df}=435$, sig. $=.000$ ) therefore normal and acceptable for factor analysis.

Table 2 KMO and Bartlett's test

\begin{tabular}{lcc}
\hline Kaiser-Meyer-Olkin measure of sampling adequacy. & .938 & \\
Bartlett's test of sphericity & Approx. chi-square & $8,390.204$ \\
& df & 435 \\
& Sig. & .000 \\
\hline
\end{tabular}

The questionnaire items used to measure each construct along with descriptive statistics are shown in Table 3. Five constructs of hair care brands are identified with the help of factor analysis. Factor loadings of the items extracted from principal component analysis and rotated by varimax with Kaiser normalisation methods are well above the threshold value 0.6 . The total variance explained by the model is approx. $78 \%$ and that is quite enough.

Table 3 Rotated component matrix

\begin{tabular}{|c|c|c|c|c|c|}
\hline Items & Construct & $\begin{array}{l}\text { Factor } \\
\text { loading }\end{array}$ & $\begin{array}{l}\text { Variance } \\
\text { explained }\end{array}$ & Mean & $S D$ \\
\hline Brand X offers very good quality products. & PQ1 & 0.841 & $18.49 \%$ & 3.324 & 1.056 \\
\hline $\begin{array}{l}\text { Brand } X \text { offers products of consistent } \\
\text { quality. }\end{array}$ & PQ3 & 0.828 & & 3.345 & 1.066 \\
\hline Brand $\mathrm{X}$ offers very reliable products. & PQ5 & 0.814 & & 3.194 & 1.040 \\
\hline $\begin{array}{l}\text { Brand } \mathrm{X} \text { offers products with excellent } \\
\text { features. }\end{array}$ & PQ4 & 0.787 & & 3.324 & 0.989 \\
\hline Brand $\mathrm{X}$ is good value for the money. & PQ2 & 0.762 & & 3.086 & 1.078 \\
\hline Brand $\mathrm{X}$ has a personality. & PQ6 & 0.723 & & 3.086 & 1.005 \\
\hline Brand $\mathrm{X}$ is interesting. & PQ7 & 0.717 & & 3.241 & 1.053 \\
\hline Brands $\mathrm{X}$ is a renowned brand. & BE4 & 0.872 & $17.78 \%$ & 3.716 & 0.872 \\
\hline Customers speak very high about brand X. & BE7 & 0.844 & & 3.522 & 0.937 \\
\hline $\begin{array}{l}\text { Brand } X \text { is a favourite brand among } \\
\text { customers. }\end{array}$ & BE1 & 0.839 & & 3.655 & 0.872 \\
\hline Brand $\mathrm{X}$ has a very good image. & BE2 & 0.819 & & 3.723 & 0.840 \\
\hline $\begin{array}{l}\text { It makes sense to buy brand } \mathrm{X} \text { instead of } \\
\text { others. }\end{array}$ & BE3 & 0.810 & & 3.442 & 0.947 \\
\hline Brand $\mathrm{X}$ would be my first choice. & BE5 & 0.789 & & 3.525 & 0.922 \\
\hline
\end{tabular}


Table 3 Rotated component matrix (continued)

\begin{tabular}{|c|c|c|c|c|c|}
\hline Items & Construct & $\begin{array}{l}\text { Factor } \\
\text { loading }\end{array}$ & $\begin{array}{l}\text { Variance } \\
\text { explained }\end{array}$ & Mean & $S D$ \\
\hline $\begin{array}{l}\text { People buy brand } \mathrm{X} \text { even if it is not } \\
\text { different from other brands. }\end{array}$ & BE6 & 0.689 & $17.78 \%$ & 3.475 & 0.953 \\
\hline $\begin{array}{l}\text { If I am going to buy, I will choose } \\
\text { brand X. }\end{array}$ & BL1 & 0.858 & $17.29 \%$ & 3.896 & 0.832 \\
\hline $\begin{array}{l}\text { I am willing to pay a premium (higher) } \\
\text { price for brand } X \text {. }\end{array}$ & BL6 & 0.857 & & 3.957 & 0.814 \\
\hline $\begin{array}{l}\text { I will not buy other brands if brand } \mathrm{X} \text { is } \\
\text { not available at the store. }\end{array}$ & BL3 & 0.851 & & 4.065 & 0.762 \\
\hline $\begin{array}{l}\text { I will not buy other brands if it is almost } \\
\text { the same like brand } X \text {. }\end{array}$ & BL4 & 0.816 & & 3.968 & 0.803 \\
\hline $\begin{array}{l}\text { I purchase my favourite brand } \mathrm{X} \text {, } \\
\text { regardless of its price. }\end{array}$ & BL5 & 0.808 & & 4.014 & 0.765 \\
\hline I consider myself loyal to the brand $X$. & BL2 & 0.799 & & 4.011 & 0.748 \\
\hline I will not buy other brands as good as X. & BL7 & 0.676 & & 4.068 & 0.705 \\
\hline I have an opinion about brand $\mathrm{X}$. & BA1 & 0.846 & $14.93 \%$ & 2.633 & 1.125 \\
\hline $\begin{array}{l}\text { I have no difficulties in imagining Brand } \\
\mathrm{X} \text { in my mind. }\end{array}$ & BA3 & 0.844 & & 2.644 & 1.177 \\
\hline I associate brand $\mathrm{X}$ with innovativeness. & BA5 & 0.825 & & 2.748 & 1.172 \\
\hline I recognise the symbol of Brand X. & BA2 & 0.817 & & 2.676 & 1.203 \\
\hline I associate brand $\mathrm{X}$ with distinctiveness. & BA4 & 0.779 & & 2.730 & 1.135 \\
\hline $\begin{array}{l}\text { Country where brand } \mathrm{X} \text { originated has an } \\
\text { innovative approach. }\end{array}$ & $\mathrm{CO} 2$ & 0.784 & $9.49 \%$ & 3.507 & 1.015 \\
\hline $\begin{array}{l}\text { Country where brand } \mathrm{X} \text { originated has } \\
\text { technological advancement. }\end{array}$ & $\mathrm{CO} 3$ & 0.761 & & 2.982 & 1.209 \\
\hline $\begin{array}{l}\text { Country where brand } \mathrm{X} \text { originated has } \\
\text { originality in workmanship. }\end{array}$ & $\mathrm{CO} 4$ & 0.732 & & 3.065 & 1.163 \\
\hline \multirow{2}{*}{$\begin{array}{l}\text { Country where brand } \mathrm{X} \text { originated has } \\
\text { creativity in designing. }\end{array}$} & $\mathrm{CO} 1$ & 0.684 & & 3.058 & 1.151 \\
\hline & Total & & $77.97 \%$ & & \\
\hline
\end{tabular}

Model reliability, validity and fit measures (Table 4) indicate that there are no issues of reliability $(\mathrm{CR}>0.7)$, convergent validity $(\mathrm{AVE}>0.5)$ and discriminant validity (MSV < AVE). Also, the square root of AVE (diagonal and bold values) greater than inter-construct correlations (Hu and Bentler, 1999). Model fit indices are also within the acceptable ranges (CMIN/DF between 1 and 3, CFI $>0.9$, SRMR $<0.08$, RMSEA $<$ $0.08)$.

Based on Baron and Kenny (1986) approach, Table 5 represents the mediation model that includes four stages:

Step 1 The regression of the outcome (BE) on the independent variable $(\mathrm{CO})$, in the absence of the mediators, is significant $\left(\mathrm{c}=.3716^{* * *}\right)$.

Step 2 The regression of the mediators (BA, BL, PQ) on the independent variable (CO) is significant $\left(\mathrm{a}_{1}=1.0368^{* * *}, \mathrm{a}_{2}=.2417^{* * *}, \mathrm{a}_{3}=.8874 * * *\right)$. 
Step 3 The regression of the outcome (BE) on the mediators (BA, BL, PQ), controlling for the independent variable $(\mathrm{CO})$, is significant $\left(\mathrm{b}_{1}=-.1303^{*}, \mathrm{~b}_{2}=.5012^{* * *}\right.$, $\left.\mathrm{b}_{3}=.2757^{* * *}\right)$.

Step 4 Regression of the outcome (BE) on the independent variable (CO) controlling for the mediators $(\mathrm{BA}, \mathrm{BL}, \mathrm{PQ})$ is insignificant $\left(\mathrm{c}^{\prime}=.1409\right)$.

Table 4 Model reliability, validity and fit measures

\begin{tabular}{lcccccccc}
\hline Items & $C R$ & $A V E$ & $M S V$ & $B D$ & $B E$ & $B L$ & $B A$ & $C O$ \\
\hline PQ & 0.949 & 0.729 & 0.504 & 0.854 & & & & \\
BE & 0.947 & 0.719 & 0.333 & 0.456 & 0.848 & & & \\
BL & 0.936 & 0.680 & 0.333 & 0.304 & 0.577 & 0.824 & & \\
BA & 0.964 & 0.842 & 0.525 & 0.710 & 0.305 & 0.256 & 0.918 & \\
CO & 0.889 & 0.668 & 0.525 & 0.690 & 0.357 & 0.228 & 0.724 & 0.817 \\
\hline \multicolumn{7}{c}{$C M I N / D F=2.476, C F I=0.930, S R M R=0.058$, RMSEA $=0.073$} & \\
\hline
\end{tabular}

Table 5 Measurement model analysis (for structural model analysis, see Appendix)

\begin{tabular}{lcccccccc}
\hline & coeff & $s e$ & $t$ & $p$ & LLCI & ULCI & Remarks & Hypothesis \\
\hline $\begin{array}{l}\mathrm{CO} \rightarrow \mathrm{BE} \\
(\mathrm{c})\end{array}$ & .3716 & .0539 & 6.8951 & .0000 & .2655 & .4777 & $\begin{array}{c}\text { Significant } \\
\text { positive }\end{array}$ & $\mathrm{H}_{\mathrm{c}}:$ Accepted \\
$\begin{array}{l}\mathrm{CO} \rightarrow \mathrm{BA} \\
\left(\mathrm{a}_{1}\right)\end{array}$ & 1.0368 & .0517 & 20.0536 & .0000 & .9350 & 1.1386 & $\begin{array}{c}\text { Significant } \\
\text { positive }\end{array}$ & $\mathrm{H}_{\mathrm{a} 1}:$ Accepted \\
$\begin{array}{l}\mathrm{CO} \rightarrow \mathrm{BL} \\
\left(\mathrm{a}_{2}\right)\end{array}$ & .2417 & .0572 & 4.2224 & .0000 & .1290 & .3544 & $\begin{array}{c}\text { Significant } \\
\text { positive }\end{array}$ & $\mathrm{H}_{\mathrm{a} 2}:$ Accepted \\
$\begin{array}{l}\mathrm{CO} \rightarrow \mathrm{PQ} \\
\left(\mathrm{a}_{3}\right)\end{array}$ & .8874 & .0487 & 18.2268 & .0000 & .7915 & .9832 & $\begin{array}{c}\text { Significant } \\
\text { positive }\end{array}$ & $\mathrm{H}_{\mathrm{a} 3}:$ Accepted \\
$\begin{array}{l}\mathrm{BA} \rightarrow \mathrm{BE} \\
\left(\mathrm{b}_{1}\right)\end{array}$ & -.1303 & .0542 & -2.4041 & .0169 & -.2370 & -.0236 & $\begin{array}{c}\text { Significant } \\
\text { negative }\end{array}$ & $\mathrm{H}_{\mathrm{b} 1}:$ Rejected \\
$\begin{array}{l}\mathrm{BL} \rightarrow \mathrm{BE} \\
\left(\mathrm{b}_{2}\right)\end{array}$ & .5012 & .0461 & 10.8737 & .0000 & .4104 & .5919 & $\begin{array}{c}\text { Significant } \\
\text { positive }\end{array}$ & $\mathrm{H}_{\mathrm{b} 2}:$ Accepted \\
$\begin{array}{l}\mathrm{PQ} \rightarrow \mathrm{BE} \\
\left(\mathrm{b}_{3}\right)\end{array}$ & .2757 & .0584 & 4.7193 & .0000 & .1607 & .3907 & $\begin{array}{c}\text { Significant } \\
\text { positive }\end{array}$ & $\mathrm{H}_{\mathrm{b} 3}:$ Accepted \\
$\begin{array}{l}\mathrm{CO} \rightarrow \mathrm{BE} \\
(\mathrm{c})\end{array}$ & .1409 & .0731 & 1.9267 & .0551 & -.0031 & .2848 & $\begin{array}{c}\text { Insignifican } \\
\text { t positive }\end{array}$ & $\mathrm{H}_{\mathrm{c}}:$ Accepted \\
\hline
\end{tabular}

\section{Discussion}

Branding has been one of the well-studied phenomena in marketing. Abundant literature is available on brand at product, company, industry and country levels. The effect of country of origin on brand equity happened where consumers observe substantial differences between the countries in terms of their product category-country relations. The present study is an attempt to measure the brand equity of hair care product in the Indian market. It also studies the mediation effect of determinants of brand equity between country-of-origin image and brand equity. The conceptual framework of the study is based on well-accepted work of Aaker (1991, 1996, 2012). According to this 
model, brand equity consists of four dimensions (brand loyalty, brand awareness, brand association and perceived quality). The outcome of the factor analysis reveals that brand awareness and brand association are not isolated and can be used as one factor.

To understand the mediation effect, the concept of Baron and Kenny (1986) is incorporated. All four assumption of the concept are met, namely; independent variable has significant positive influence on outcome in the absence of mediator(s); independent variable has significant influence on each mediator; each mediator has significant influence on outcome; and independent variable has insignificant influence on outcome in the presence of mediator(s). To understand full/partial mediation effects, the recent submission of Kenny (2016) is useful. He argues,

\begin{abstract}
"The steps are stated in terms of zero and nonzero coefficients, not in terms of statistical significance (Baron and Kenny, 1986)... The steps should not be defined in terms of statistical significance.... Another measure of mediation is the proportion of the effect that is mediated, or the indirect effect divided by the total effect or $\mathrm{ab} / \mathrm{c}$ or equivalently $1-\mathrm{c}^{\prime} / \mathrm{c}$.... I would advise only computing this measure if standardised $\mathrm{c}$ is at least $\pm .20 \ldots$. One rule of thumb is that if one wants to claim complete mediation ab/c should be at least .80."
\end{abstract}

Based on the above statement, present study on the hair care products determines that the dimensions of brand equity partially mediate the relationship between country-of-origin image and the brand equity $\left(1-\mathrm{c}^{\prime} / \mathrm{c}=.20<.62<.80\right)$. It is consistent with the previous literature that states that brand equity dimensions could account for a significant amount of variance in the relationship between brand equity and country-of-origin image. Since the country-of-origin image is a positive predictor of brand equity, the model expects that higher country-of-origin image affects higher brand equity. In addition, higher country-of-origin image leads to higher brand equity dimensions.

\title{
7 Conclusions
}

The results of the present study concludes that findings are mostly consistent with the previous literature. Country-of-origin image as causal variable directly and positively influences the brand equity of hair care brands. It shows that if consumers are unaware of the attributes of the hair care brand, purchases are influenced according to the country-of-origin image. For example, if a new/unknown brand of the hair care product is launched, consumer will prefer 'Made in France' rather than 'Made in China'. Country-of-origin image also positively influences the brand equity dimensions of hair care brands. It also demonstrates that better country-of-origin image will enhance the brand loyalty, brand awareness/association and perceived quality of the brand. In addition, these dimensions also significantly influence brand equity. Both brand loyalty and perceived quality of the hair care brands positively influence the brand equity. However, brand awareness/association shows a significant negative relationship with brand equity. It indicates that consumers have a negative awareness/association with brand equity of hair care brands. This outcome reflects that hair care product possesses a negative recognition/opinion due to its attributes, ingredients or side effects. The results of mediation analysis confirm the partial mediation of country-of-origin image on brand equity. It reveals that in the absence of any mediator, the brand equity of hair care brand 
is significantly influence by its country-of-origin image. However, in the presence of mediators, the effect of country-of-origin image on brand equity diminishes.

\section{Implications}

If the attributes of the hair care product are unknown to the consumers, country-of-origin image plays an important role to create an opinion about the brand. Marketers should highlight the positive image of country-of-origin of the brand if either product is new in market or consumers have lack of sufficient product knowledge. Increased product knowledge tends to improve the brand equity dimensions, which reduces the impact of country-of-origin image on brand equity. Therefore, in case of negative image of country, marketers should emphasise in creating extensive brand image messages in terms of brand loyalty, awareness, association, and quality of their hair care products. These findings are helpful to the hair care industry specifically and other industries in general. Marketers will be able to get the critical insight of brand equity and its dimensions. It will also enhance the understanding of the relationship between country-of-origin image and brand equity with and without mediators. Researchers and academicians will be benefited to understand the various issues of branding and able to conduct further researches in other industries and markets. One of the future researches would be to study the images of various countries and its impact on brand equity of various products made in these countries. If the country's image is weak, researches can be done to improve brand equity to subside the effect of country-of-origin image.

\section{References}

Aaker, D. (1991) Managing Brand Equity: Capitalizing on the Value of a Brand Name, The Free Press, New York, NY.

Aaker, D. (1996) 'Measuring brand equity across products and markets', California Management Review, Vol. 38, No. 3, pp.102-120.

Aaker, D. (2012) Building Strong Brands, Simon and Schuster, New York, NY.

Akhtar, N., Siddiqi, U.I., Ashraf, A. and Latif, M. (2016) 'Impact of a brand equity on consumer purchase decision in L'Oreal skincare products', International Review of Management and Business Research, Vol. 5, No. 3, p.808.

Akkucuk, U. and Esmaeili, J. (2016) 'The impact of brands on consumer buying behavior: an empirical study on smartphone buyers', International Journal of Research in Business and Social Science (2147-4478), Vol. 5, No. 4, p.1 [online] https://doi.org/10.20525/ijrbs.v5i4.551.

Al-Aali, A., Randheer, K. and Hasin, S. (2015) 'Do the subcomponents of country of origin trigger purchase intentions?: A conceptual model of consumer perceptions', International Journal of Commerce and Management, Vol. 25, No. 4, pp.627-640 [online] https://doi.org/10.1108/ IJCoMA-05-2013-0047.

Amiri, S. and Maroofi, F. (2016) 'The relationship between brand awareness, market outcome, brand equity, and the marketing mix', International Journal of Markets and Business Systems, Vol. 2, No. 1, p.68 [online] https://doi.org/10.1504/IJMABS.2016.078108.

Atilgan, E., Aksoy, Ş. and Akinci, S. (2005) 'Determinants of the brand equity: a verification approach in the beverage industry in Turkey', Marketing Intelligence \& Planning, Vol. 23, No. 3, pp.237-248.

Ayyildiz, H. and Cengiz, E. (2007) 'Country image effect on customer loyalty model', Innovative Marketing, Vol. 3, No.2, pp.44-64. 
Azadi, R., Yousefi, B. and Eydi, H. (2015) 'The impact of brand country-of-origin image on the formation of brand equity in the sports apparel industry', Universal Journal of Industrial and Business Management, Vol. 3, No. 3, pp.67-73.

Bahrinizadeh, M., Esmaiilpoor, M. and Haraghi, M. (2014) 'Brand equity and country of origin model in pharmaceutical industry', Kuwait Chapter of the Arabian Journal of Business and Management Review, Vol. 3, No. 6, p.137.

Baldinger, A.L. (1990) 'Defining and applying the brand equity concept', Journal of Advertising Research, Vol. 30, No. 3, p.RC2.

Ballester, E.D. and Alemán, J.L.M. (2005) 'Does brand trust matter to brand equity?', Journal of Product \& Brand Management, Vol. 14, No. 3, pp.187-196.

Bariar, S., Jain, V. and Verma, A.V. (2016) 'An investigation of the factors influencing consumer perception towards green brands', Research Journal of Commerce Behavioural Science, Vol. 5, No. 5, pp.11-23.

Baron, R.M. and Kenny, D.A. (1986) 'The moderator-mediator variable distinction in social psychological research: conceptual, strategic, and statistical considerations', Journal of Personality and Social Psychology, Vol. 51, No. 6, p.1173.

Bassan, L. and Kathuria, L.M. (2016) 'Understanding dimensions of customer-based brand equity in banks', International Journal of Business Competition and Growth, Vol. 5, Nos. 1/2/3, p.21 [online] https://doi.org/10.1504/IJBCG.2016.079931.

Belén del Río, A., Vazquez, R. and Iglesias, V. (2001) 'The effects of brand associations on consumer response', Journal of Consumer Marketing, Vol. 18, No. 5, pp.410-425.

Bello, D.C. and Holbrook, M.B. (1995) 'Does an absence of brand equity generalize across product classes?', Journal of Business Research, Vol. 34, No. 2, pp.125-131.

Bilkey, W.J. and Nes, E. (1982) 'Country-of-origin effects on product evaluations', Journal of International Business Studies, Vol. 13, No. 1, pp.89-100.

Blythe, J. (2007) 'Advertising creatives and brand personality: a grounded theory perspective', Journal of Brand Management, Vol. 14, No. 4, pp.284-294.

Buil, I., Martínez, E. and de Chernatony, L. (2013) 'The influence of brand equity on consumer responses', Journal of Consumer Marketing, Vol. 30, No. 1, pp.62-74.

Cassia, F., Hsu, M.C., Choy, K.L. and Lee, T.R. (2017) 'Developing a comprehensive brand evaluation system with the support of TRIZ to formulate brand strategies', International Journal of Business Excellence, Vol. 11, No. 1, p.38 [online] https://doi.org/10.1504/ IJBEX.2017.10000676.

Chattopadhyay, T., Shivani, S. and Krishnan, M. (2008) 'Approaches towards measuring brand equity', presented at the Oxford Business \& Economics Conference, Oxford Business and Economics Journal, June [online] http://www.gcbe.us/2008_OBEC/data/confcd.htm (accessed 22 November 2017).

Cordell, V.V. (1992) 'Effects of consumer preferences for foreign sourced products', Journal of International Business Studies, Vol. 23, No. 2, pp.251-269.

Datta, B. and Mukherjee, S. (2017) 'Ethical dimension of customer-based brand equity', International Journal of Business Excellence, Vol. 13, No. 1, p.91 [online] https://doi.org/ 10.1504/IJBEX.2017.10006233.

Fathi, S., Ranjbarian, B. and Ghafari, M. (2017) 'Developing a brand equity model for tourism destination', International Journal of Business Innovation and Research, Vol. 12, No. 4, p.484 [online] https://doi.org/10.1504/IJBIR.2017.10003337.

Grover, R. and Srinivasan, V. (1992) 'Evaluating the multiple effects of retail promotions on brand loyal and brand switching segments', Journal of Marketing Research, Vol. 29, No. 1, pp.76-89. 
Haghighi, M., Afrasiabi, N. and Moetamedzadeh, H.R. (2013) 'Analysis and prediction of how advertisement influences brand equity using new methods of artificial intelligence: a case study on branches of Pasargad Bank in Tehran, Iran', Global Journal of Science, Engineering and Technology, Vol. 5, pp.134-141.

Hameed, F. (2013) 'The effect of advertising spending on brand loyalty mediated by store image, perceived quality and customer satisfaction: a case of hypermarkets', Asian Journal of Business Management, Vol. 5, No. 1, pp.181-192.

Hamzaoui, L. and Merunka, D. (2006) 'The impact of country of design and country of manufacture on consumer perceptions of bi-national products' quality: an empirical model based on the concept of fit', Journal of Consumer Marketing, Vol. 23, No. 3, pp.145-155.

Hanaysha, J., Abdullah, H.H. and Ghani, N.H.A. (2016) 'Importance of product quality and service quality in developing brand equity', J. for Global Business Advancement, Vol. 9, No. 4, p.390 [online] https://doi.org/10.1504/JGBA.2016.079883.

Hankinson, G. and Cowking, P. (1996) The Reality of Global Brands: Cases and Strategies for the Successful Management of International Brands, McGraw-Hill Book, Maidenhead, UK.

Hayes, A.F. (2017) Introduction to Mediation, Moderation, and Conditional Process Analysis: A Regression-Based Approach, Guilford Publications, New York, NY.

Hilman, H. and Hanaysha, J. (2015) 'The impact of country of origin on relationship quality: empirical evidence from automotive industry', Mediterranean Journal of Social Sciences, Vol. 6, No. 2, p.165.

Hosseini, M.H. and Saravi Moghadam, N. (2017) 'A model of customer-based brand equity: evidence from the banking service in Iran', International Journal of Productivity and Quality Management, Vol. 21, No. 1, p.23 [online] https://doi.org/10.1504/IJPQM.2017.10003944.

Hu, L. and Bentler, P.M. (1999) 'Cutoff criteria for fit indexes in covariance structure analysis: conventional criteria versus new alternatives', Structural Equation Modeling: A Multidisciplinary Journal, Vol. 6, No. 1, pp.1-55.

Huber, J. and McCann, J. (1982) 'The impact of inferential beliefs on product evaluations', Journal of Marketing Research, Vol. 19, No. 3, pp.324-333.

Keller, K.L. (1993) 'Conceptualizing, measuring, and managing customer-based brand equity', The Journal of Marketing, Vol. 57, No. 1, pp.1-22.

Keller, K.L., Parameswaran, M.G. and Jacob, I. (2011) Strategic Brand Management: Building, Measuring, and Managing Brand Equity, Pearson Education, India.

Kenny, D.A. (2016) Mediation [online] http://davidakenny.net/cm/mediate.htm (accessed 3 December 2017)

Kim, C.K. (1995) 'Brand popularity and country image in global competition: managerial implications', Journal of Product \& Brand Management, Vol. 4, No. 5, pp.21-33.

Kumar, R.S., Dash, S. and Purwar, P.C. (2013) 'The nature and antecedents of brand equity and its dimensions', Marketing Intelligence \& Planning, Vol. 31, No. 2, pp.141-159.

Lassar, W., Mittal, B. and Sharma, A. (1995) 'Measuring customer-based brand equity', Journal of Consumer Marketing, Vol. 12, No. 4, pp.11-19 [online] https://doi.org/10.1108/ 07363769510095270.

Lee, H., Chen, T. and Guy, B.S. (2014) 'How the country-of-origin image and brand name redeployment strategies affect acquirers' brand equity after a merger and acquisition', Journal of Global Marketing, Vol. 27, No. 3, pp.191-206.

Lin, C. and Kao, D.T. (2004) 'The impacts of country-of-origin on brand equity', Journal of American Academy of Business, Vol. 5, Nos. 1/2, pp.37-40.

Lin, L. and Chen, C-S. (2006) 'The influence of the country-of-origin image, product knowledge and product involvement on consumer purchase decisions: an empirical study of insurance and catering services in Taiwan', Journal of Consumer Marketing, Vol. 23, No. 5, pp.248-265. 
Mahyari, H.K., Abareshi, A., Asian, S. and Pool, J.K. (2018) 'An examination of the interplay between country-of-origin, brand equity, brand preference and purchase intention toward global fashion brands', International Journal of Business Forecasting and Marketing Intelligence, Vol. 4, No. 1, p.43 [online] https://doi.org/10.1504/IJBFMI.2018.10009308.

Mostafa, R.H. (2015) 'The impact of country of origin and country of manufacture of a brand on overall brand equity', International Journal of Marketing Studies, Vol. 7, No. 2, p.70.

Mutsikiwa, M., Dhliwayo, K. and Basera, C.H. (2013) 'The impact of advertising on building brand equity: a case of Zimbabwean universities', European Journal of Business and Management, Vol. 5, No. 9, pp.197-210.

Nagashima, A. (1970) 'A comparison of Japanese and US attitudes toward foreign products', The Journal of Marketing, Vol. 34, No. 1, pp.68-74.

Ngoc, C.T. (2014) 'Understanding the relationship between country of origin image and brand equity-case of cosmetic brands in Ho Chi Minh City', International Proceedings of Economics Development and Research, Vol. 78, p.12.

Oliver, R.L. (1997) 'Emotional expression in the satisfaction response', Satisfaction: A Behavioral Perspective on the Consumer, pp.291-325, Irwin, Boston.

Opoku, R., Abratt, R. and Pitt, L. (2006) 'Communicating brand personality: are the websites doing the talking for the top South African Business Schools?', Journal of Brand Management, Vol. 14, Nos. 1-2, pp.20-39.

Panda, R.K. and Misra, S. (2014) 'Impact of country-of-origin image on brand equity: a study on durable products in India', Procedia-Social and Behavioral Sciences, Vol. 150, pp.494-499.

Pappu, R., Quester, P.G. and Cooksey, R.W. (2006) 'Consumer-based brand equity and country-oforigin relationships: some empirical evidence', European Journal of Marketing, Vol. 40, Nos. 5/6, pp.696-717.

Parameswaran, R. and Yaprak, A. (1987) 'A cross-national comparison of consumer research measures', Journal of International Business Studies, Vol. 18, No. 1, pp.35-49.

Research and Markets (2017) Hair Care in India [online] https://www.researchandmarkets.com/ reports/219947/hair_care_in_india (accessed 23 November 2017).

Rondán Cataluña, F.J., García, A.N. and Phau, I. (2006) 'The influence of price and brand loyalty on store brands versus national brands', Int. Rev. of Retail, Distribution and Consumer Research, Vol. 16, No. 4, pp.433-452.

Sanyal, S.N. and Datta, S.K. (2011) 'The effect of country of origin on brand equity: an empirical study on generic drugs', Journal of Product \& Brand Management, Vol. 20, No. 2, pp.130-140.

Saydan, R. (2013) 'Relationship between country of origin image and brand equity: empirical evidence in the English Market', International Journal of Business and Social Science, Vol. 4, No. 3, pp.78-88.

Shahin, A., Kazemi, A. and Mahyari, H.K. (2012) H'ow consumer's perception of country of origin affects brand equity: a case study in Iran', Middle-East Journal of Scientific Research, Vol. 12, No. 6, pp.878-885.

Shahrokh, Z.D. and Azodi, A.D. (2013) 'The effect of country of origin image on brand equity and purchase intention', Journal of Applied Environmental and Biological Sciences, Vol. 3, No. 12 , pp.52-61.

Shocker, A.D. and Weitz, B. (1988) 'A perspective on brand equity principles and issues', Report, No. 88-104, pp.2-4.

Srikatanyoo, N. and Gnoth, J. (2002) 'Country image and international tertiary education', The Journal of Brand Management, Vol. 10, No. 2, pp.139-146.

Steenkamp, J E.M. (1997) 'Dynamics in consumer behavior with respect to agricultural and food products', in Agricultural Marketing and Consumer Behavior in a Changing World, p.143, Springer, Boston, MA. 
Thorelli, H.B., Lim, J-S. and Ye, J. (1989) 'Relative importance of country of origin, warranty, and retail store image on product evaluations', International Marketing Review, Vol. 6, No. 1, pp.35-46.

Tong, X. and Hawley, J.M. (2009) 'Measuring customer-based brand equity: empirical evidence from the sportswear market in China', Journal of Product \& Brand Management, Vol. 18, No. 4, pp.262-271.

Yasin, N.M., Noor, M.N. and Mohamad, O. (2007) 'Does image of country-of-origin matter to brand equity?', Journal of Product \& Brand Management, Vol. 16, No. 1, pp.38-48.

Ye, G. and Raaij, W.F.V. (2004) 'Brand equity: extending brand awareness and liking with signal detection theory', Journal of Marketing Communications, Vol. 10, No. 2, pp.95-114.

Yoo, B. and Donthu, N. (2001) 'Developing and validating a multidimensional consumer-based brand equity scale', Journal of Business Research, Vol. 52, No. 1, pp.1-14.

Yoo, B., Donthu, N. and Lee, S. (2000) 'An examination of selected marketing mix elements and brand equity', Journal of the Academy of Marketing Science, Vol. 28, No. 2, pp.195-211.

Zeithaml, V.A. (1988) 'Consumer perceptions of price, quality, and value: a means-end model and synthesis of evidence’, The Journal of Marketing, Vol. 52, No. 3, pp.2-22.

\section{Appendix}

Figure A1 Regression of the outcome on the independent variable, without the mediators (see online version for colours)

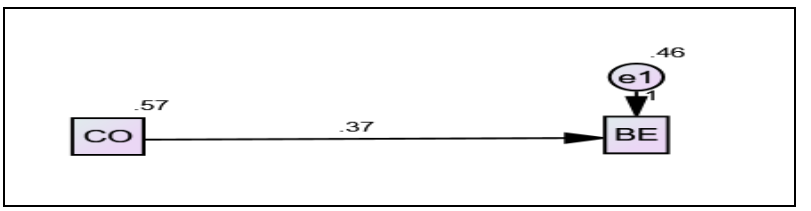

Figure A2 Regression of the outcome on the independent variable, with the mediators (see online version for colours)

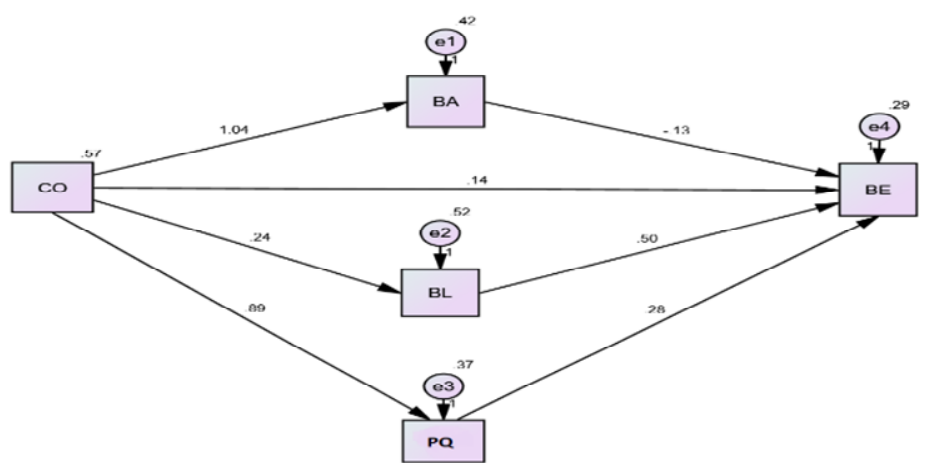


************** PROCESS Procedure for SPSS Release 2.16.3 $* * * * * * * * * * * * * * * * * * * *$

Written by Andrew F. Hayes, Ph.D (http://www.afhayes.com)

Documentation available in Hayes (2013) (http://www.guilford.com/p/hayes3)

Model $=4$

$\mathrm{Y}=\mathrm{BE}$

$\mathrm{X}=\mathrm{CO}$

$\mathrm{M} 1=\mathrm{BA}$

$\mathrm{M} 2=\mathrm{BL}$

$\mathrm{M} 3=\mathrm{PQ}$

Sample size $=278$

$* * * * * * * * * * * * * * * * * * * * * * * * * * * * * * * * * * * * * * * * * * * * * * * * * * * * * * * * * * * * * * * * * * * * * * * *$ Outcome: BA

Model summary

$\begin{array}{lllllll}\mathrm{R} & \mathrm{R}-\mathrm{sq} & \mathrm{MSE} & \mathrm{F} & \mathrm{df} 1 & \mathrm{df} 2 & \mathrm{p}\end{array}$

$\begin{array}{lllllll}.7701 & .5930 & .4251 & 402.1457 & 1.0000 & 276.0000 & .0000\end{array}$

Model

\begin{tabular}{lccccccc|c|} 
& coeff & $\mathrm{se}$ & $\mathrm{t}$ & $\mathrm{p}$ & LLCI & ULCI & \\
Constant & -.0063 & .1365 & -.0464 & .9630 & -.2751 & .2624 & \multirow{2}{*}{. $\mathrm{a}_{1}$} \\
CO & $\mathbf{1 . 0 3 6 8}$ & $\mathbf{. 0 5 1 7}$ & $\mathbf{2 0 . 0 5 3 6}$ & $\mathbf{. 0 0 0 0}$ & $\mathbf{. 9 , 3 5 0}$ & $\mathbf{1 . 1 3 8 6}$ & \\
\end{tabular}

************************************************************************** Outcome: BL

Model summary

$\begin{array}{lcccccc}\text { R } & \text { R-sq } & \text { MSE } & \text { F } & \text { df1 } & \text { df2 } & p \\ .2463 & 0.607 & .5211 & 17.8284 & 1.0000 & 276.0000 & .0000\end{array}$

Model

\begin{tabular}{lccccccc|c|} 
& coeff & $\mathrm{se}$ & $\mathrm{t}$ & $\mathrm{p}$ & LLCI & ULCI & \\
Constant & 3.6757 & .1512 & 24.3171 & .0000 & 3.3782 & 3.9733 & \multirow{2}{*}{$\mathrm{a}_{2}$} \\
CO & $\mathbf{. 2 4 1 7}$ & $\mathbf{. 0 5 7 2}$ & $\mathbf{4 . 2 2 2 4}$ & $\mathbf{. 0 0 0 0}$ & $\mathbf{. 1 2 9 0}$ & $\mathbf{. 3 5 4 4}$ & \\
\end{tabular}


Outcome: PQ

Model summary

$\begin{array}{lcccccc}\text { R } & \text { R-sq } & \text { MSE } & \text { F } & \text { df1 } & \text { df2 } & \text { p } \\ .7391 & .5462 & .3769 & 332.2177 & 1.0000 & 276.0000 & .0000\end{array}$

Model

\begin{tabular}{lccccccc|cr} 
& coeff & $\mathrm{se}$ & $\mathrm{t}$ & $\mathrm{p}$ & LLCI & ULCI & \\
Constant & 1.0622 & .1286 & 8.2932 & .0000 & .8131 & 1.3193 & \multirow{2}{*}{ 的 } \\
CO & $\mathbf{. 8 8 7 4}$ & $\mathbf{. 0 4 8 7}$ & $\mathbf{1 8 . 2 2 6 8}$ & $\mathbf{. 0 0 0 0}$ & $\mathbf{. 7 9 1 5}$ & $\mathbf{. 9 8 3 2}$ & \\
\hline
\end{tabular}

$* * * * * * * * * * * * * * * * * * * * * * * * * * * * * * * * * * * * * * * * * * * * * * * * * * * * * * * * * * * * * * * * * * * * * * * * *$

Outcome: BE

Model summary

$\begin{array}{lcccccc}\text { R } & \text { R-sq } & \text { MSE } & \text { F } & \text { df1 } & \text { df2 } & p \\ .6839 & .4677 & .2913 & 59.7777 & 4.0000 & 273.0000 & .0000\end{array}$

Model

\begin{tabular}{lccccccc|} 
& coeff & $\mathrm{se}$ & $\mathrm{t}$ & $\mathrm{p}$ & $\mathrm{LLCI}$ & $\mathrm{ULCI}$ & \\
Constant & .3983 & .2040 & 1.9521 & .0519 & -.0034 & .8000 & \\
BA & $\mathbf{- . 1 3 0 3}$ & $\mathbf{. 0 5 4 2}$ & $\mathbf{- 2 . 4 0 4 1}$ & $\mathbf{. 0 1 6 9}$ &.$- \mathbf{2 3 7 0}$ & $\mathbf{- . 0 2 3 6}$ & $\leftarrow \mathrm{b}_{1}$ \\
BL & $\mathbf{. 5 0 1 2}$ & $\mathbf{. 0 4 6 1}$ & $\mathbf{1 0 . 8 7 3 7}$ & $\mathbf{. 0 0 0 0}$ & $\mathbf{. 4 1 0 4}$ & $\mathbf{. 5 9 1 9}$ & $\leftarrow \mathrm{b}_{2}$ \\
PQ & $\mathbf{. 0 5 8 4}$ & $\mathbf{4 . 7 1 9 3}$ & $\mathbf{. 0 0 0 0}$ & $\mathbf{. 1 6 0 7}$ & $\mathbf{. 3 9 0 7}$ & & $\leftarrow \mathrm{b}_{3}$ \\
CO & $\mathbf{. 1 4 0 9}$ & $\mathbf{. 0 7 3 1}$ & $\mathbf{1 . 9 2 6 7}$ & $\mathbf{0 . 5 5 1}$ & $\mathbf{. 0 0 3 1}$ & $\mathbf{. 2 8 4 8}$ & $\leftarrow$ c \\
\hline
\end{tabular}

****************************TOTAL EFFECT MODEL $* * * * * * * * * * * * * * * * * * * * * *$

Outcome: BE

Model summary

$\begin{array}{lcccccc}\text { R } & \text { R-sq } & \text { MSE } & \text { F } & \text { df1 } & \text { df2 } & p \\ .3833 & .1469 & .4619 & 47.5429 & 1.0000 & 276.0000 & .0000\end{array}$

Model

\begin{tabular}{lccccccc|c|} 
& coeff & $\mathrm{se}$ & $\mathrm{t}$ & $\mathrm{p}$ & LLCI & ULCI & \\
Constant & 2.5352 & .1423 & 17.8146 & .0000 & 2.2551 & 2.8154 & \multirow{2}{*}{ c } \\
CO & $\mathbf{. 3 7 1 6}$ & $\mathbf{. 0 5 3 9}$ & $\mathbf{6 . 8 9 5 1}$ & $\mathbf{. 0 0 0 0}$ & $\mathbf{. 2 6 5 5}$ & $\mathbf{. 4 7 7 7}$ & \\
\hline
\end{tabular}

****************** TOTAL, DIRECT, AND INDIRECT EFFECTS $* * * * * * * * * * * * * *$

Total effect of $\mathrm{X}$ on $\mathrm{Y}$

$\begin{array}{llllll}\text { Effect } & \mathrm{SE} & \mathrm{t} & \mathrm{p} & \text { LLCI } & \text { ULCI }\end{array}$

$\begin{array}{llllll}.3716 & .0539 & 6.8951 & .0000 & .2655 & .4777\end{array}$

Direct effect of $\mathrm{X}$ on $\mathrm{Y}$

.1409

SE

t

1.9267

$\mathrm{p}$

LLCI

ULCI

$\leftarrow \mathrm{c}^{\prime}$

.0731

.0551

$-.0031$

.2848 
Indirect effect of $\mathrm{X}$ on $\mathrm{Y}$

\begin{tabular}{lccccc|} 
& Effect & Boot SE & BootLLCI & BootULCI & \\
TOTAL & .2307 & .0702 & .0861 & .3643 & $\leftarrow$ c-c' \\
BA & -.1351 & .0598 & -.2509 & -.0151 & $\leftarrow a_{1}{ }^{*} b_{1}$ \\
BL & .1211 & .0309 & .0657 & .1858 & $\leftarrow a_{2}{ }^{*} b_{2}$ \\
PQ & $\mathbf{2 4 4 7}$ & .0549 & .1442 & .3607 & $\leftarrow a_{3}{ }^{*} b_{3}$ \\
\cline { 2 - 6 }
\end{tabular}

********************** ANALYSIS NOTES AND WARNINGS $* * * * * * * * * * * * * * * * * *$

Number of bootstrap samples for bias corrected bootstrap confidence intervals: 5,000.

Level of confidence for all confidence intervals in output: 95.00. 